GUINSBURG, Jacó; KOUDELA, Ingrid Dormien. (org., trad. e notas). Buchner na pena e na cena. São Paulo: Editora Perspectiva, 2004. 382p.

\title{
Na pena, a cena
}

Luiz Nazario*

Georg Büchner é um daqueles poucos escritores que, à maneira de um Kleist, de um Rimbaud ou de um Kafka, abandonaram o mundo cedo demais, deixando uma obra inacabada, feita mais de fragmentos que de grandes peças inteiras, e que mesmo assim conseguiram imprimir uma marca indelével na História da Literatura. Büchner poderia ser inscrito entre os autores que Gilles Deleuze reivindica para seu conceito de "literatura menor", freqüentemente mais intensa e verdadeira que a chamada "grande literatura": "Grande e revolucionário, somente o menor", ele escreveu, em Kafka: por uma literatura menor [Rio de Janeiro: Imago Editora, p. 40].

Raros foram os escritores que conseguiram tanta expressividade e concisão. Enquanto Elias Canetti, já muito influenciado por Kafka, escrevia seu Auto-de-fé, talvez o melhor romance do século XX, sua companheira Veza, que ao contrário dele já lera as obras completas de Büchner num pequeno volume em papel bíblia, escondia-o no fundo da estante do quarto, bem atrás das obras de Victor Hugo; nesse lugar ela sabia que o amante não tocaria, e assim o impedia de descobrir um autor tão moderno que seria capaz de esterilizar Canetti em seu mergulho no universo dos loucos e desajustados.

Quando, por acaso, Canetti encontrou um volume amarelo da peça Woyzeck e o devorou durante uma noite sem sono, foi bater de madrugada na porta de Veza para xingá-la por nunca ter mencionado a existência de tal autor. Ela revelou a trapaça, e tirou do buraco o volume da Insel, indicando-lhe a leitura dessa maravilhosa novela inacabada que é Lenz - a primeira descrição detalhada de um estado esquizofrênico na literatura alemã. Canetti pôs-se a devorá-la com avidez, depois de ouvir de Veza a explicação para ter-lhe seqüestrado Büchner: como sabia que ele o amaria com todo seu amor, e como o poder da escrita desse autor esgotaria suas forças criativas, ela temera pelo futuro de seu trabalho; agora que ele havia concluído o último capítulo de Auto-de-fé, podia sofrer o abalo cósmico daquelas leituras.

Também no Brasil, graças à Editora Perspectiva, já podemos viver a mesma experiência. Pela primeira vez foram publicadas as obras completas - ou quase (os editores deixaram de lado apenas as cartas sem maior interesse literário) - de Georg Büchner. Realizada com grande apuro estilístico por Jacó Guinsburg e Ingrid Dormien Koudela, a tradução já seria digna de todos os elogios. Contudo, atento às necessidades do leitor brasileiro, carente de uma formação histórica mais aprofundada, os editores enriqueceram didaticamente o texto de $A$ morte de Danton com notas de rodapé que constituem um livro à parte - uma pequena história da Revolução Francesa contada através da biografia de seus líderes.

Mais uma vez, a espantosa erudição de Jacó Guinsburg nos encanta e instrui. Podemos, finalmente, mergulhar no universo trágico (mesmo quando se pretende cômico, como na peça Leonce e Lena), de Büchner, um autor sempre atual, com seus personagens sexualmente exasperados e politicamente desencantados, tendo esses heróis amargos percebido que o sexo é apenas um entorpecente e que toda revolução devora, como Saturno, seus próprios filhos. No limite da humanidade, esses seres carentes e infelizes só desejam, depois de uma existência sem sentido, a dignidade da morte. Mas, no universo sem piedade de Büchner, mesmo a dignidade mínima do momento final é negada aos homens: eis uma antevisão dos horrores que estavam por vir numa Alemanha sem coração. 
Sob as cinzas da revolução democrática vislumbrada por Georg Büchner em 1883 n'O mensageiro de Essen, floresceria de forma lenta, mas segura, um movimento inteiramente voltado para o Mal; exatamente um século depois, esse movimento, também vislumbrado pelos expressionistas, que o fixaram em pavorosas sombras alongadas, encontraria seu ninho numa exaltada multidão de corações vazios, e triunfaria, negando, a milhões de judeus, assassinados em massa apenas por terem nascido, tanto a dignidade da vida quanto a dignidade da morte.

* Luiz Nazario é professor de Cinema na Escola de Belas-Artes da UFMG. Coordena o projeto "Cinema e Holocausto" com Bolsa de Produtividade do CNPq. Autor de, entre outros: Da natureza dos monstros, 1998; As sombras móveis, 1999; Autos de fé como espetáculos de massa, 2005 e Todos os corpos de Pasolini, de 2007. 